\title{
Role of biological habitat amelioration in altering the relative responses of congeneric species to climate change
}

\author{
P. Moore ${ }^{1,2,4, *}$, S. J. Hawkins ${ }^{1,2,3}$, R. C. Thompson ${ }^{2}$ \\ ${ }^{1}$ Marine Biological Association of the UK, The Laboratory, Citadel Hill, Plymouth PL1 2PB, UK \\ ${ }^{2}$ Marine Biology and Ecology Research Centre, School of Biological Sciences, University of Plymouth, \\ Plymouth PL4 8AA, UK \\ ${ }^{3}$ School of Biological Sciences, University of Southampton, Southampton SO16 7PX, UK \\ ${ }^{4}$ Present address: Centre of Excellence for Coral Reef Studies, Centre for Marine Studies, University Queensland, \\ Brisbane, 4072 Queensland, Australia
}

\begin{abstract}
The distribution of most species is expected to alter in response to climate change. Predictions for the extent of these range shifts are frequently based on 'climate envelope' approaches, which often oversimplify species responses because many do not consider interactions between physical and biological factors. The local persistence of some species, however, is likely to be strongly modulated by microhabitat-forming organisms. Using congeneric patellid gastropods with northern/ boreal and southern/lusitanian distributions, we have demonstrated how the loss of habitat-forming macroalgal species could modify species responses to climate change. The northern limpet Patella vulgata preferentially aggregates beneath Fucus spp. When Fucus vesiculosus was experimentally removed, to simulate a decline in macroalgal abundance in response to climatic warming, $P$. vulgata suffered increased mortality or relocated home scars, often to nearby Fucus spp. patches. In contrast, the southern limpet $P$. depressa did not aggregate beneath Fucus spp. and showed no response in terms of movement or mortality to the loss of $F$. vesiculosus. Based on these results, we predict that the loss of Fucus spp. will influence the relative abundance of these 2 limpet species, particularly at the distributional limit of Fucus spp. In addition, differences in the aggregative behaviour of these limpet species will result in changes in the spatial distribution of grazing in the intertidal, with likely consequences for community dynamics. These outcomes could not be anticipated from predictions based on direct responses to temperature alone, highlighting the need for biotic and abiotic factors to be incorporated into predictions of species responses to climate change.
\end{abstract}

KEY WORDS: Biological interactions $\cdot$ Biologically generated habitat $\cdot$ Climate change $\cdot$ Climate envelope $\cdot$ Limpets $\cdot$ Macroalgae

\section{INTRODUCTION}

Global air temperatures have risen by $0.6 \pm 0.2^{\circ} \mathrm{C}$ in the last $100 \mathrm{yr}$ and further increases of between 2 and $3^{\circ} \mathrm{C}$ are predicted by 2100 (Hulme et al. 2002), prompting the need to understand how species and assemblages respond to climate change. To date, forecasts of species-level responses have used a 'climate envelope' approach, whereby a single climatic variable, usually temperature, is mapped in 'climate space' (the area in which a species can survive because the environment is suitable). If the climatic space alters, then it is predicted that the geographical distribution of species found within that climatic space will alter accordingly (Pearson \& Dawson 2003). This approach can be useful (Hodkinson 1999, Pearson \& Dawson 2003), but it has also been criticised because it tends to predict a species' fundamental (or potential) niche and does not 
take into account biological interactions, dispersal capability, habitat quality, together with habitat availability and connectivity, all of which influence a species' realised niche (Davis et al. 1998, Pearson \& Dawson 2003). Here, we use the rocky intertidal as a convenient model system to investigate the role of behaviourally mediated direct and indirect biological interactions in modifying species' responses to climate change and the likely consequence for community structure and dynamics.

The British Isles straddle 2 major marine biogeographic zones, with both warm lusitanian and cool boreal biota (Lewis 1964). As a consequence, many of the species present are at either the northern or southern edge of their biogeographic ranges (Southward et al. 1995), resulting in sets of ecologically comparable species, with northern and southern centres of distribution co-existing and with abundances which have been shown to fluctuate with climatic changes (Southward 1967, Southward et al. 1995). Therefore, southwest Britain provides an ideal region in which to investigate how species with northern and southern biogeographic distributions respond to climate change and, in particular, the way in which biotic interactions may modify these responses.

A general poleward movement of species' ranges in response to global warming has been predicted (Parmesan 1996), although see Helmuth et al. (2006) for discussion of local factors, such as time of low water, influencing species' range shifts. Evidence of changes in the relative abundance of species with northern and southern biogeographic distributions, as well as poleward and upward latitudinal shifts in species' ranges, have been observed in a wide range of taxonomic groups during the twentieth century (Walther et al. 2002). These shifts are evident in both aquatic and terrestrial habitats, including coastal waters where plankton (Beaugrand \& Ibanez 2004), intertidal organisms (Southward et al. 1995) and fish (Genner et al. 2004, Perry et al. 2005) have all shown responses.

Canopy-forming fucoid algae are conspicuous members of the community of all but the most exposed rocky shores of the NE Atlantic (Lewis 1964). Midshore fucoids are a cold temperate/boreal group of species that becomes less abundant with decreasing latitude (Ballantine 1961). Thus, it is anticipated that fucoids will become restricted to more northerly latitudes or buffered environments if temperatures rise (Franklin \& Forster 1997). For example, 'climate envelope' models predict that, with an increase in temperature of 1 to $2{ }^{\circ} \mathrm{C}$, Fucus vesiculosis, the dominant midshore algal species on moderately exposed shores, would be lost from most of south-west Britain (M. T. Burrows unpubl. data). There is some evidence to suggest that this northward range retraction has already started, with some cold-temperate canopy-forming species, such as Laminaria spp. (Breeman 1990, A. E. F. Murias Dos Santos unpubl. data), Himanthalia elongata and Pelvetia canaliculata (A. E. F. Murias Dos Santos unpubl. data), already becoming scarcer at their southern range limits.

Canopy-forming algae influence community structure by modifying the environment (Menge 1978). Higher concentrations of microalgal food are found beneath algal canopies (Thompson et al. 2004), where environmental conditions are ameliorated and habitats are generated for other species (Leonard 2000), often resulting in increased diversity (e.g. Fucus spp. at midshore heights in Britain, Thompson et al. 1996; and Cystoseira spp. at low-shore levels in the Mediterranean, Benedetti-Cecchi et al. 2001). Hence, it is likely that the presence/absence of canopy-forming algae will have a disproportionate effect on the distribution and diversity of species in the intertidal, with implications for assemblage dynamics.

Limpets are key grazers on rocky shores in the NE Atlantic, and strongly influence community structure and dynamics by controlling macroalgal abundance (Southward \& Southward 1978, Hawkins et al. 1992). Two species of limpet co-exist at midshore levels on moderately exposed shores of south-west Britain: Patella vulgata, a cold-temperate/boreal limpet, distributed from northern Norway to southern Portugal, and $P$. depressa, a southern/lusitanian limpet, distributed from Senegal in West Africa to north Wales, UK (Southward et al. 1995). It is predicted that P. depressa will become the dominant limpet on the shores of south-west Britain, at the expense of P. vulgata, in response to increased climatic warming (Southward et al. 1995), and there is evidence to suggest this is already occurring on some shores (S. J. Hawkins unpubl. data).

Both species of limpet exhibit 'homing' behaviour, returning to the same home scar between foraging excursions (Hawkins et al. 1992), and their spatial distribution influences the probability of Fucus spp. (here after Fucus) becoming established via escapes from grazing (Hartnoll \& Hawkins 1985). Conversely, Fucus influences the distribution of many intertidal species including limpets (Menge 1978, Hawkins et al. 1992, Thompson et al. 1996, Leonard 2000, Jenkins et al. 2005). Thus, whilst Patella spp. control the initial development of fucoid stands, once established, fucoids provide 'nursery' grounds for juvenile $P$. vulgata and a microhabitat for adult $P$. vulgata that aggregate under patches of Fucus. In contrast, $P$. depressa does not appear to aggregate under Fucus patches (S. J. Hawkins unpubl. data).

Here, we explore the direct and indirect effects of Fucus canopy loss on these 2 closely related limpet 
species to demonstrate how responses to climate change can be modulated by biological interactions mediated by intrinsic differences in behaviour. Such interactions are likely to alter predictions for species' range shifts based on the direct effects of climate change on setting distributional limits. The relationships between Fucus patches and both Patella vulgata and $P$. depressa were examined to determine the extent to which each species aggregates beneath Fucus. Manipulative field experiments were then used to investigate the responses of both limpet species to the loss of Fucus. Responses were quantified in terms of changes in behaviour - in this case, both the distance moved to locate a new home scar and mortality. Specifically, we examined the hypothesis that the loss of Fucus would have a much greater effect on the behaviour and mortality of $P$. vulgata than on that of $P$. depressa, by effectively reducing $P$. vulgatas' preferred habitat.

\section{MATERIALS AND METHODS}

Spatial distribution of northern and southern limpet species in relation to Fucus patches. The spatial distribution of the limpets Patella depressa and $P$. vulgata in relation to Fucus were compared independently of each other at each of 2 locations: Trevone $\left(50^{\circ} 55^{\prime} \mathrm{N}, 4^{\circ} 98^{\prime} \mathrm{W}\right)$ and Crackington Haven $\left(50^{\circ} 74^{\prime} \mathrm{N}\right.$, $\left.4^{\circ} 64^{\prime} \mathrm{W}\right)$, on the north coast of Cornwall, UK. The abundance of $P$. vulgata and $P$. depressa was recorded in Fucus patches and on areas of open rock using 10 randomly placed $0.5 \times 0.5 \mathrm{~m}$ quadrats for each species-habitat combination. The effect of macroalgal canopy on the relative abundance of $P$. vulgata and $P$. depressa was then compared using a 3-factor ANOVA, with the factor location (2 levels) considered random and the factors habitat (2 levels: with or without macroalgal canopy) and species (2 levels: P. vulgata or P. depressa) considered fixed.

To provide an indication of the differences in temperature limpets may experience beneath Fucus patches and on open rock, 3 temperature data loggers (Thermochron ${ }^{\circledR}$ ibutton DS1921G) were allocated to each of 3 areas of open rock and beneath Fucus patches at Crackington Haven during typical summer low-tide weather conditions in 2004.

Limpet mortality and behaviour following loss of Fucus. The effect of the loss of Fucus vesiculosis (hereafter Fucus) on the mortality and behaviour of Patella vulgata and $P$. depressa was investigated experimentally at Trevone and Crackington Haven. Both shores are moderately exposed, with areas of open rock, barnacle-covered rock and a mosaic of Fucus patches. Experiments were run between June and September in both 2002 and 2003. At midshore level, 20 areas with patches of Fucus of approximately $0.09 \mathrm{~m}^{2}$ in size were randomly allocated to 2 treatments: Fucus present (unmanipulated control) or Fucus removal. In the Fucus removal treatments, Fucus canopy (including holdfast) was removed from the substrate with a scalpel. Ten areas of open rock were also selected to act as controls. Responses of $P$. vulgata and $P$. depressa were monitored independently of each other in each of 5 replicate plots for each of the 3 treatments. Five $P$. vulgata or $P$. depressa were randomly selected within each experimental plot; these individuals were measured and double tagged with micro-numbers glued to the shell with cyanoacrylate.

The response variables measured were distance moved to a new home scar and mortality. To quantify relocation to new home scars the position of each limpet was recorded using coordinates from a $1 \mathrm{~m}^{2}$ grid separated into $0.03 \mathrm{~m}^{2}$ grid squares. Limpet positions prior to treatment manipulations were taken to be the limpets' initial home scars, as limpets are generally inactive and on their homes scars at midshore levels while the tide is out. Analyses were carried out on the distance limpets moved from their initial home scar at the completion of the experiment 4 mo later. The position of each individual was then determined every $14 \mathrm{~d}$ during low water when the limpets were not active (i.e. on their home scars) to ensure that micro-numbers were still attached to limpet shells and to monitor mortality. In cases in which limpets had relocated from their original home scar, the habitat to which they had moved was noted. Where limpets were missing from plots, a 15 min search of the surrounding area (approximately $9 \mathrm{~m}^{2}$ ) was made, and, if the limpets were not found, they were assumed to have died. Total mortality across the 4 mo of the experiment was used for analysis.

In 2002, a large number of limpets from all treatments at Trevone died, probably as a consequence of natural sand scour in some of the experimental areas; therefore, only the Crackington Haven experiment was analysed for this period. In 2003, comparisons were possible between Trevone and Crackington Haven. Two-factor ANOVA was used to compare differences in response variables (distance moved from original home scar at the completion of the experiment and mortality over the course of the experiment) between the 3 treatments at Crackington Haven in 2002. The factors treatment ( 3 levels) and species (2 levels) were considered fixed. In 2003, a third factor, location (2 levels and random), was also examined to establish spatial consistency. The number of individual limpets available for analysis of distance moved to a new home scar was unequal, due to differential mortality between treatments, so data were randomly 
removed from treatments to create a balanced design. For all analyses, heterogeneity of variance was examined using Cochran's test, and, where appropriate, data were $\log (x+1)$ transformed. In order to increase the power when comparing factors of interest, posthoc pooling was utilised to remove non-significant terms $(p>0.25)$. Student-Newman-Keuls (SNK) posthoc tests were carried out on significant results ( $p<$ 0.05).

\section{RESULTS}

\section{Spatial distribution of northern and southern limpet species in relation to Fucus patches}

There were significant differences in the spatial distribution of Patella vulgata and $P$. depressa in relation to Fucus patches at both Trevone and Crackington Haven. The abundance of $P$. vulgata was significantly higher beneath Fucus patches than on open rock (Table 1). In contrast, the abundance of $P$. depressa was significantly higher on open rock than beneath Fucus patches $\left(F_{1,73}=133.87 ; \mathrm{p}<0.01\right.$; Fig. 1$)$.

Temperature data loggers confirmed the potential for Fucus patches to ameliorate conditions during low tide, with temperatures beneath Fucus patches (mean \pm SE: $20.59 \pm 0.11^{\circ} \mathrm{C}$ ) on average $5^{\circ} \mathrm{C}$ cooler than temperatures experienced on open rock (25.68 \pm $\left.0.22^{\circ} \mathrm{C}\right)$.

\section{Limpet mortality and behaviour following loss of Fucus}

Patella vulgata experienced significantly higher mortality in Fucus removal treatments (approximately $40 \%$ ) than in unmanipulated Fucus patches (approximately $20 \%$ ) and on open rock (approximately $24 \%$ ). There was no difference in the levels of mortality for $P$. depressa amongst the 3 treatments. These patterns were evident at Crackington Haven in $2002\left(F_{2,17}=\right.$ 4.66, p < 0.05; Table 2, Fig. 2a) and were consistent at both Trevone and Crackington Haven in $2003\left(F_{2,50}=\right.$ 3.75, p < 0.05; Table 2, Fig. 2b). At Crackington Haven in 2002, P. depressa suffered significantly higher levels of mortality compared to $P$. vulgata in the open rock treatments.

The distance moved to a new home scar by Patella vulgata following experimental removal of Fucus was greater than that of $P$. depressa in all treatments and than that of $P$. vulgata under Fucus patches and on open rock. This behaviour was consistent at Crackington Haven in $2002\left(F_{2,66}=8.97, \mathrm{p}<0.01\right.$; Table 3, Fig. 2c) and across locations in $2003\left(F_{2,194}=3.4, \mathrm{p}<\right.$
Table 1. ANOVA for the abundance of Patella vulgata and $P$. depressa beneath Fucus patches and on emergent rock at 2 locations (Crackington Haven and Trevone) in south-west Britain [ln $(x+1)$ transformation; Cochran's test: $C=0.2008$, non-significant]. Location $\times$ habitat $\times$ species was nonsignificant $(p>0.25)$ and was thus pooled with the residual to increase the power of the test for the treatment $\times$ species interaction

\begin{tabular}{|c|c|c|c|c|c|c|}
\hline Source & SS & $\mathrm{df}$ & MS & $F$ & $\mathrm{p}$ & $F$ vs. \\
\hline Location (Lo) & 3.84 & 1 & 3.84 & 15.54 & $<0.01$ & 1-Pooled \\
\hline Habitat (Ha) & 9.70 & 1 & 9.70 & 99.57 & 0.06 & Lo $\times$ Ha \\
\hline Species (Sp) & 30.46 & 1 & 30.46 & 504.05 & $<0.05$ & $\mathrm{Lo} \times \mathrm{Sp}$ \\
\hline $\mathrm{Lo} \times \mathrm{Ha}$ & 0.10 & 1 & 0.10 & 0.39 & 0.53 & 1-Pooled \\
\hline Lo $\times \mathrm{Sp}$ & 0.06 & 1 & 0.06 & 0.24 & 0.62 & 1-Pooled \\
\hline $\mathrm{Ha} \times \mathrm{Sp}$ & 33.07 & 1 & 33.07 & 133.87 & $<0.01$ & 1-Pooled \\
\hline $\mathrm{Lo} \times \mathrm{Ha} \times \mathrm{Sp}$ & 0.04 & 1 & 0.04 & 0.15 & 0.70 & 1-Pooled \\
\hline Residual & 17.99 & 72 & 0.25 & & & \\
\hline Total & 95.25 & 79 & & & & \\
\hline 1-Pooled & & 73 & 0.25 & & & \\
\hline \multicolumn{7}{|c|}{$\begin{array}{l}\text { SNK tests } \\
P . \text { vulgata, Fucus patch }>P \text {. vulgata, open rock } \\
P \text {. depressa, open rock }>\text { P. depressa, Fucus patch }\end{array}$} \\
\hline
\end{tabular}

0.05; Table 3, Fig. 2d). The maximum distance an individual $P$. vulgata moved to relocate their home scar following Fucus removal was approximately $2 \mathrm{~m}$. Of the P. vulgata that survived following Fucus removal, 36\% from Crackington Haven in 2002 and $25 \%$ from Trevone and Crackington Haven in 2003 relocated home scars to beneath another Fucus patch

In contrast, Patella depressa at both locations in 2003 stayed loyal to their home scars in all treatments, irrespective of the presence or absence of Fucus. At Crackington Haven in 2002, P. depressa moved a small, but significant, distance from their home scars in unmanipulated Fucus patch treatments (mean \pm SE: $12.2 \pm 2.9 \mathrm{~cm})$ compared to in Fucus removal $(3.3 \pm$

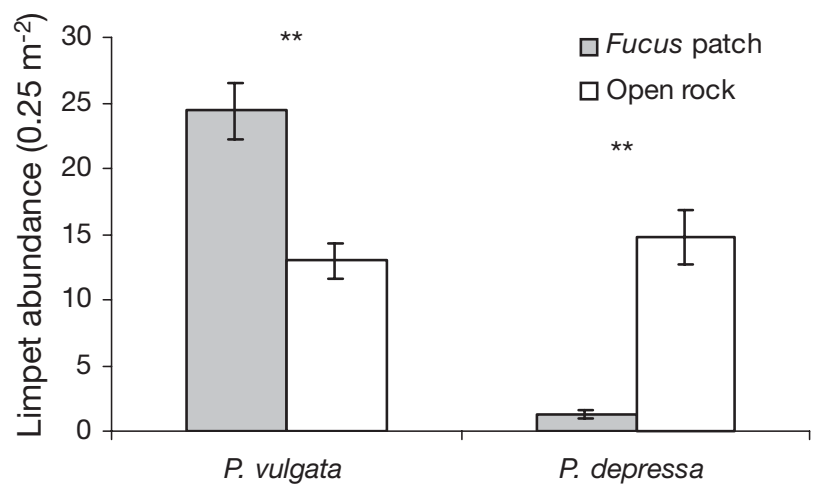

Fig. 1. Patella vulgata and P. depressa. Effect of macroalgal cover (Fucus vesiculosus) on the relative abundance of limpets at Crackington Haven and Trevone (means $\pm 1 \mathrm{SE}$ ) $\left({ }^{* *} \mathrm{p}<0.01\right)$ 


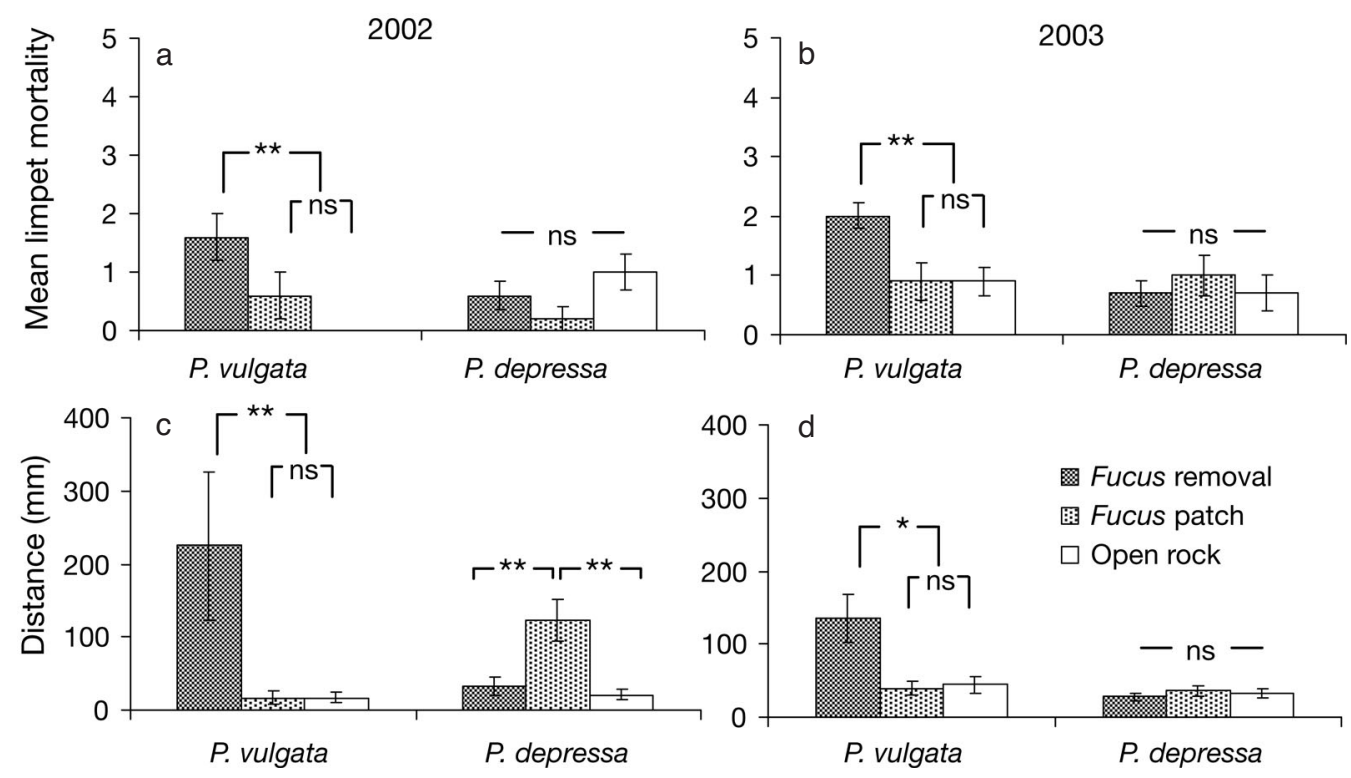

Fig. 2. Patella vulgata and P. depressa. Response to the experimental loss of Fucus vesiculosus for: treatment $\times$ species interaction for mortality at (a) Crackington Haven in 2002 and (b) Trevone and Crackington Haven in 2003; treatment $\times$ species interaction for distance moved to a new home scar at (c) Crackington Haven in 2002 and (d) Trevone and Crackington Haven in 2003 (means $\pm 1 \mathrm{SE})\left({ }^{*} \mathrm{p}<0.05 ;{ }^{* *} \mathrm{p}<0.01, \mathrm{~ns}\right.$ : non-significant)

suffer increased levels of mortality on open rock compared to $P$. vulgata, but this perhaps reflects greater intrinsic rates of mortality of $P$. depressa compared to $P$. vulgata (Boaventura et al. 2002). The reasons for the difference in behaviour between $P$. vulgata and $P$. depressa in relation to Fucus are not clear. Fucus is absent over much of the biogeographic range of $P$. depressa, so the lack of a response by $P$. depressa to the loss of Fucus patches may be a direct result of the limited overlap in their biogeographic ranges. Alternatively, there is some evidence to suggest that $P$. depressa does less well beneath Fucus patches compared to on open rock (Southward \& Southward 1978, Moore et al. in press), and may actively avoid creating home scars beneath Fucus patches.

In laboratory studies both species of limpet have been shown to withstand and recover from exposure to temperatures close to $43^{\circ} \mathrm{C}$ (lethal temperatures: Patella vulgata, $42.8^{\circ} \mathrm{C}$ and $P$. depressa, $43.3^{\circ} \mathrm{C}$; Evans 1948); however, no work has been done on the temperature tolerances of these 2 species in the field. Recent work has shown that congeneric species with cold/ boreal biogeographic distributions were more temperature sensitive than those with warmer/lusitanian distributions (Stillman 2003). In addition species may be able to initially survive exposure to extreme temperatures, but thermal damage experienced as a result of the exposure may prove fatal in the future (Stenseng et al. 2005). Therefore, although both species have been shown to survive similar temperature extremes, $P$. vulgata may still be more temperature sensitive than $P$. depressa. The amelioration of temperature extremes beneath canopy algae may explain the preferential aggregation of $P$. vulgata beneath Fucus patches and the relocation of home scars beneath new Fucus patches as well as the increased mortality when canopy algae is experimentally removed. Hence, the local persistence of $P$. vulgata may be partly reliant on the presence of its preferred habitat, Fucus patches.

It is unlikely that selective predation resulted in the increased mortality of Patella vulgata in Fucus removal treatments. The main predators of limpets are birds, crabs, whelks and fish (Thompson et al. 2000). There is no evidence of any selection for $P$. vulgata or $P$. depressa by these predators (e.g. Coleman et al. 1999 for birds and Thompson et al. 2000 for crabs), or, in the case of oystercatchers, a preference for foraging on open or Fucus-covered rock (Coleman et al. 1999).

\section{Biotic interactions modify species responses to climate change}

Amelioration of environmental conditions by organisms such as canopy-forming algae has been well documented. However, the role of these habitatgenerating species will become more important as warming increases, since limpets, littorinids, whelks, anemones and numerous other species will increasingly become restricted to habitats where climatic extremes are buffered (Leonard 2000, Jenkins et al. 2005). For example, in the USA, habitat amelioration has been 
shown to increase the survival and persistence of the northern barnacle Semibalanus balanoides, whose survivorship was increased by shading by macroalgae at hotter southern sites, but not at cooler northern sites (Bertness et al. 1999, Leonard 2000). Furthermore, a study of high-level salt marsh plants in New England found that the plants experienced facilitative effects of neighbouring plants at hotter southern sites, but not at cooler northern sites (Bertness \& Ewanchuk 2002). Therefore, if warming continues as predicted, the local persistence of many species may become more dependent on the presence of others, and shifts in species' distributions may become magnified where biologically generated habitats are lost or reduced.

If climatic warming increases, the abundance of Patella depressa at sites in Britain is predicted to increase, while the abundances of $P$. vulgata and Fucus are predicted to decrease. However, when the interaction of these 2 limpet species with Fucus is incorporated, it is apparent that a stepped response in the relative abundance of the 2 limpet species is likely to occur, particularly at the edge of the distributional boundary of Fucus. At this boundary the abundance of P. vulgata may decrease sharply as a consequence of increased environmental stress resulting from the loss of its preferred micro-habitat (Fucus canopy). In contrast, the abundance of $P$. depressa may rapidly increase at the boundary as more of its preferred habitat (open rock) becomes available. This switch in the relative abundance of $P$. vulgata and $P$. depressa is apparent when the proportion of the 2 limpet species is compared between shores in south-west Britain (mean proportion of P. depressa, 0.30; Jenkins et al. 2001), where Fucus can be abundant, and shores $7^{\circ}$ (approximately $800 \mathrm{~km}$ ) further south in northern Spain (mean proportion of $P$. depressa, 0.81; Jenkins et al. 2001), where Fucus becomes rare on open coasts (Ballantine 1961). If, as predicted, canopy algae, such as Fucus vesiculosis, respond to increased warming faster than $P$. vulgata, without incorporation of the modifying ('engineering') effect of Fucus on local microhabitats, predictions of future range shifts are likely to be inaccurate. For example, 'climate envelope' models based solely on changes in sea-surface temperature and wave action forecast little change in the distribution of $P$. vulgata in the British Isles (M. T. Burrows unpubl. data). This is unlikely to be the case if canopy-forming algae disappear, as expected, on shores in south-west Britain.

\section{Community-level responses to local changes in grazer distribution}

The grazing behaviour of Patella vulgata contributes to the conspicuous mosaic of variously aged macro- algal patches common on many moderately exposed shores of the NE Atlantic (Lewis 1964, Hartnoll \& Hawkins 1985, Hawkins et al. 1992), which, in turn, influence the community structure of rocky shores, because a higher diversity of organisms is found beneath Fucus patches compared to in areas of adjacent emergent rock (Thompson et al. 1996). P. vulgata plays a key role in structuring rocky shore communities because of its aggregative behaviour, which can lead to a patchy distribution of grazing intensity that enables Fucus escapes to occur (Hartnoll \& Hawkins 1985). Our data show that $P$. depressa does not preferentially aggregate beneath Fucus patches, and this is likely to result in a more even distribution of grazing activity. Initial studies also indicate that $P$. depressa may be less effective at controlling macroalgal abundance than $P$. vulgata on shores in south-west Britain (Moore et al. in press). Hence, changes in the spatial distribution of grazers and the level of grazing intensity could have broad-scale implications for macroalgal abundance. Manipulation of canopyforming algae has been shown to result in changes in the diversity and abundance of other algal species (Dayton 1975, Benedetti-Cecchi et al. 2001) and results in a reduction in the diversity and abundance of invertebrates (Benedetti-Cecchi et al. 2001). Therefore, changes in macroalgal cover are likely to have broad-scale implications for rocky shore community dynamics.

\section{Predicting responses to climate change}

Our findings are supported by work carried out in mesocosms (Davis et al. 1998) and by experimental field studies (Bertness et al. 1999, Leonard 2000), which have highlighted the need to incorporate biotic interactions into predictions of species' future biogeographic distributions. The present study has shown, in the case of Patella vulgata and P. depressa, that the presence or absence of Fucus canopy may alter the speed at which these 2 species respond to increased climatic warming. Therefore, if future predictions on the effects of climate change do not include effects on the survival of Fucus, then it is unlikely that realistic predictions of range shifts by these limpet species can be made. Recent work has also shown that variability in the physical environment is often greater within sites than that experienced over larger geographic areas (Benedetti-Cecchi et al. 2000); therefore, future predictions of species' range shifts need to be made at appropriate spatial (and temporal) scales. 'Climate envelope' models may be able to provide a first approximation of species' responses to climate change; however, these models have the potential to be highly inaccurate if they do not take into account biotic 
interactions and are undertaken at an inappropriate scale (Hellmuth et al. 2006). 'Climate envelope' models incorporating multiple species, to account for biotic interactions, and measurements of the physical environment made at the appropriate scales are therefore fundamental in providing more biologically realistic predictions of species' range and abundance shifts in response to climatic change.

Acknowledgements. P.M. was funded by a joint studentship from the University of Plymouth and the Marine Biological Association of the UK. S.J.H. was supported by NERC via a NERC grant-in-aid funded fellowship. S.J.H., R.C.T. and P.M. were also funded by the MarClim consortium (Countryside Council for Wales; The Crown Estates; Department for Environment, Food and Rural Affairs; English Nature; Environment Agency; Joint Nature Conservation Committee; Scottish Executive; Scottish Natural Heritage; States of Jersey and Worldwide Fund for Nature). We appreciate the comments of 4 reviewers, who greatly improved the manuscript.

\section{LITERATURE CITED}

Ballantine WJ (1961) A biologically-defined exposure scale for the comparative description of rocky shores. Field Stud 1:73-84

Beaugrand G, Ibanez F (2004) Monitoring marine plankton ecosystems. II. Long-term changes in North Sea calanoid copepods in relation to hydro-climatic variability. Mar Ecol Prog Ser 284:35-47

Benedetti-Cecchi L, Bulleri F, Cinelli F (2000) The interplay of physical and biological factors in maintaining mid-shore and low-shore assemblages on rocky coasts in the northwest Mediterranean. Oecologia 123:406-417

Benedetti-Cecchi L, Pannacciulli FG, Bulleri F, Moschella PS, Airoldi L, Relini G, Cinelli F (2001) Predicting the consequences of anthropogenic disturbance: large-scale effects of loss of canopy algae on rocky shores. Mar Ecol Prog Ser 214:137-150

Bertness MD, Leonard GH, Levine JM, Bruno JF (1999) Climate-driven interactions among rocky intertidal organisms caught between a rock and a hot place. Oecologia 120:446-450

Bertness MD, Ewanchuk PJ (2002) Latitudinal and climatedriven variation in the strength and nature of biological interactions in New England salt marshes. Oecologia 132: 392-401

Boaventura D, Fonseca LCD, Hawkins SJ (2002) Analysis of competitive interactions between the limpets Patella depressa Pennant and Patella vulgata L. on the northern coast of Portugal. J Exp Mar Biol Ecol 271:171-188

Breeman AM (1990) Expected effects of changing sea-water temperatures on the geographic distribution of seaweed species. In: Beukema JJ, Wolff WJ, Brouns JJWM (eds) Expected effects of climate change on marine coastal ecosystems. Kluwer Academic Publishers, Dordrecht, p 69-76

Coleman RA, Goss-Custard JD, Durell SEAV, Hawkins SJ (1999) Limpet Patella spp. consumption by oystercatchers Haematopus ostralegus: a preference for solitary prey items. Mar Ecol Prog Ser 193:253-261

Davis AJ, Jenkinson LS, Lawton JH, Shorrocks B, Wood S (1998) Making mistakes when predicting shifts in species range in response to global warming. Nature 391:783-786

Dayton PK (1975) Experimental evaluation of ecological dominance in a rocky intertidal algal community. Ecol Monogr 45:137-159

Evans RG (1948) The lethal temperatures of some common British littoral molluscs. J Anim Ecol 17:165-173

Franklin LA, Forster RM (1997) The changing irradiance environment: consequences for marine macrophyte physiology, productivity and ecology. Eur J Phycol 32:207-232

Genner MJ, Sims DW, Wearmouth VJ, Southall EJ, Southward AJ, Henderson PA, Hawkins SJ (2004) Regional climatic warming drives long-term community changes of British marine fish. Proc R Soc Lond B 271:655-661

Hartnoll RG, Hawkins SJ (1985) Patchiness and fluctuations on moderately exposed rocky shores. Ophelia 24:53-63

Hawkins SJ, Hartnoll RG, Kain JM, Norton TA (1992) Plant-animal interactions on hard substrata in the northeast Atlantic. In: John DM, Hawkins SJ, Price JH (eds) Plant animal interactions in the marine benthos. Systematics Association Special, Vol 46, Clarendon Press, Oxford, p 1-32

Helmuth B, Mieszkowska N, Moore P, Hawkins SJ (2006) Living on the edge of two changing worlds: forecasting the responses of rocky intertidal ecosystems to climate change. Annu Rev Ecol Evol Syst 37:373-404

Hodkinson ID (1999) Species response to global environmental change or why ecophysiological models are important: a reply to Davis et al. J Anim Ecol 68:1259-1262

Hulme M, Jenkins GJ, Lu X, Turnpenny JR and 8 others (2002) Climate change scenarios for the United Kingdom: the UKCIP02 scientific report. Tyndall Centre for Climate Change Research, School of Environmental Sciences, University of East Anglia, Norwich

Jenkins SR, Coleman RA, Della Santina P, Hawkins SJ, Burrows MT, Hartnoll RG (2005) Regional scale differences in the determinism of grazing effects in the rocky intertidal. Mar Ecol Prog Ser 287:77-86

Jenkins SR, Arenas F, Arrontes J, Bussell J and 10 others (2001) European-scale analysis of seasonal variability in limpet grazing activity and microalgal abundance. Mar Ecol Prog Ser 211:193-203

Leonard GH (2000) Latitudinal variation in species interactions: a test in the New England rocky intertidal zone. Ecology 81:1015-1030

Lewis JR (1964) The ecology of rocky shores. English Universities Press, London

Menge BA (1978) Predation intensity in a rocky intertidal community: effect of an algal canopy, wave action and desiccation on predator feeding rates. Oecologia 34:17-35

Moore P, Thompson RC, Hawkins SJ (in press) Effects of grazer identity on the probability of a canopy-forming macroalga. J Exp Mar Biol Ecol

Parmesan C (1996) Climate and species range. Nature 382: 765-766

Pearson RG, Dawson TP (2003) Predicting the impacts of climate change on the distribution of species: Are bioclimate envelope models useful? Global Ecol Biogeogr 12:361-371

Perry AL, Low PJ, Ellis JR, Reynolds JD (2005) Climate change and distribution shifts in marine fishes. Science 308:1912-1915

Southward AJ (1967) Recent changes in abundance of intertidal barnacles in south-west England: a possible effect of climatic deterioration. J Mar Biol Assoc UK 47:81-95

Southward AJ, Southward EC (1978) Recolonization of rocky shores in Cornwall after use of toxic dispersants to clean up the Torrey Canyon spill. J Fish Res Board Can 35: $682-706$ 
Southward AJ, Hawkins SJ, Burrows MT (1995) Seventy years' observations of changes in distribution and abundance of zooplankton and intertidal organisms in the western English Channel in relation to rising sea temperature. J Therm Biol 20:127-155

Stenseng E, Braby CE, Somero GN (2005) Evolutionary and acclimation-induced variation in the thermal limits of heart function in congeneric marine snails (genus Tegula): implications for vertical zonation. Biol Bull (Woods Hole) 208:138-144

Stillman JH (2003) Acclimation capacity underlies susceptibility to climate change. Science 301:65

Thompson RC, Wilson BJ, Tobin ML, Hill AS, Hawkins SJ

Editorial responsibility: Howard Browman (Associate Editorin-Chief), Storebø, Norway
(1996) Biologically generated habitat provision and diversity of rocky shore organisms at a hierarchy of spatial scales. J Exp Mar Biol Ecol 202:73-84

Thompson RC, Jenkins SR, Bussell JA (2000) A method for recording predator-prey encounters between crabs and limpets using wax replicas. J Mar Biol Assoc UK 80:633-638

Thompson RC, Norton TA, Hawkins SJ (2004) Physical stress and biological control regulate the balance between producers and consumers in marine intertidal biofilms. Ecology 85:1372-1382

Walther GR, Post E, Convey P, Menzel A and 5 others (2002) Ecological responses to recent climate change. Nature 416:389-395

Submitted: March 17, 2006; Accepted: September 1, 2006 Proofs received from author(s): March 18, 2007 